\title{
Post-Gastrectomy Osteomalacia Mimicking Rheumatologic Disorders: A Case Report
}

\author{
Than Than Aye ${ }^{1}$ and Htar Ni Aye ${ }^{2}$ \\ ${ }^{1}$ Department of Endocrinology, University of Medicine 2, Yangon, Myanmar \\ ${ }^{2}$ Myint Thaw Dar Specialist Clinic, Yangon, Myanmar
}

\begin{abstract}
Osteomalacia is one of the post-gastrectomy complications resulting from the impaired absorption of vitamin $D$ and calcium. ${ }^{1}$ Vitamin D deficiency or osteomalacia can be diagnosed by clinical, biochemical and radiographic parameters, and bone biopsy. The radiologic findings of "Looser zones" or pseudofractures aid in the diagnosis. Severe generalized pain, mimicking rheumatologic disorders is one of the features that maybe a presenting complaint of osteomalacia. We report a case of osteomalacia as a consequence of gastric by-pass surgery.
\end{abstract}

Key words: osteomalacia, post-gastrectomy, malabsorption, Looser zones

\section{INTRODUCTION}

Osteomalacia is a condition of defective skeletal mineralization in adults. Generalized aches and pain may be one of the presenting features in osteomalacia and it can be overlooked and misdiagnosed as a rheumatological disorder. Vitamin D deficiency is a recognized complication of gastric by-pass surgery due to malabsorption of vitamin D and calcium.

\section{CASE}

A 33-year-old Indian woman presented with the complaint of generalized body pain. Previously she had been treated as a case of rheumatoid arthritis by her primary care doctor. She had been frequently taking various analgesics for the pain, which she had felt for many years. The pain was non-specific and not welllocalized but more noticeable in the four extremities, shoulders and chest. Severe pain was experienced even with light touch. She also complained of difficulty in getting up from a sitting position.

She had a gastric bypass surgery at the age of 14 for complicated peptic ulcer. Since then, she had been having frequent loose bowel movement, with no apparent blood, mucus or steatorrhoea. Other than worsening with intake of coffee, tea or milk, there were no other specific identified aggravating factors for the diarrhea. During this time, she experienced repeated attacks of epigastric pain and vomiting of gastric contents and occasional bile-stained fluid. She became fastidious with her diet and only ate rice, beans and dried fish. She also felt weak and breathless on exertion.

eISSN 2308-118x

Printed in the Philippines

Copyright (C) 2016 by the JAFES

Received: September 10, 2015. Accepted: January 30, 2016

http://dx.doi.org/10.15605/jafes.031.01.10
On physical examination, the patient appeared pale and thin, with a body weight of $41.8 \mathrm{~kg}$, height of $1.63 \mathrm{~m}$, and body mass index of $15.8 \mathrm{~kg} / \mathrm{m}^{2}$. Her blood pressure was $90 / 60 \mathrm{mmHg}$ and pulse rate was $88 / \mathrm{min}$. Respiratory and cardiovascular examinations were normal. Abdominal examination was unremarkable apart from a surgical scar. On examination of the musculoskeletal system, there was neither joint swelling nor deformity. Tenderness was elicited on pressure over her chest and limbs. On neurological examination, there was no significant neurologic deficit.

Initial laboratory tests revealed a hemoglobin level of 8.6 $\mathrm{g} / \mathrm{dL}$, with a mean corpuscular volume of $63 \mathrm{fL} / \mathrm{cell}$ (Table 1). The white cell count, platelet, ESR, blood urea and electrolytes were within normal range (Table 2). Biochemical analysis for malabsorption revealed iron deficiency anemia, with low serum iron $(5.14 \mu \mathrm{mol} / \mathrm{L})$, low serum ferritin $(7.14 \mathrm{ng} / \mathrm{mL})$ and normal total iron-binding capacity $(59 \mu \mathrm{mol} / \mathrm{L})$. Corrected calcium level was also low (2.1 mmol/L). Vitamin B12, serum folate and serum albumin levels were within normal limits. To exclude other causes of malabsorption like celiac disease, antigliadin antibodies and anti-endomysium IgA was done and were negative. Viral and bacterial causes of enteritis, such as antibodies to HIV, hepatitis B, hepatitis C and mycobacterium, were all negative. Fecal studies showed absence of reducing sugar, glucose, occult blood and fat globules. Other endocrine disorders were excluded by normal serum cortisol and thyroid function tests (Table 3). Tests for rheumatologic disorders such as rheumatoid factor, anti-nuclear antibody and antibody to extracted nuclear antigen profile were negative (Table 4).

Corresponding author: Prof. Than Than Aye,

MBBS, MMed Sc (Internal Medicine), MRCP (UK), FRCP (Edin), FRCP (London)

D.T.M \& H (London), Dr.Med.Sc (Gen.Med)

President, Myanmar Society of Endocrinology and Metabolism

Professor Emeritus, University of Medicine 2, Yangon, Myanmar

No.18, Kan Street, Hlaing Township, Yangon, Myanmar 11051

Tel. No.: 959-5060558

E-mail: profthanthanaye@gmail.com 
Table 1. Hematologic assays

\begin{tabular}{lll}
\hline Variable & Result & Reference range \\
\hline Haemoglobin, g/dL & 8.6 & $11.5-16.5$ \\
Red blood cell count, $\times 10^{12} / \mathrm{L}$ & 4.7 & $3.9-5.6$ \\
Mean corpuscular volume, fL & 63 & $76-96$ \\
Platelet count, $\times 10^{9} / \mathrm{L}$ & 316 & $150-400$ \\
White blood cell count, $\times 10^{9} / \mathrm{L}$ & 5.4 & $4-11$ \\
Neutrophil, \% & $40 \%$ & $40-75$ \\
Lymphocyte, \% & $50 \%$ & $20-45$ \\
Monocyte, \% & $7 \%$ & $2-10$ \\
Eosinophil, \% & $3 \%$ & $0-6$ \\
Basophil, \% & $0 \%$ & $0-2$ \\
ESR, mm/1 ${ }^{\text {st }}$ hour & 15 & $6-12$ \\
Vitamin B12, pg/mL & 421 & $200-900$ \\
Serum folate, ng/mL & 10.1 & $4.6-16$ \\
Serum iron, $\mu \mathrm{mol} / \mathrm{L}$ & 5.14 & $6.6-26$ \\
Total iron-binding capacity, $\mu \mathrm{mmol} / \mathrm{L}$ & 59 & $49-69$ \\
Serum ferritin, $\mathrm{ng} / \mathrm{mL}$ & 7.14 & $13-150$ \\
\hline & &
\end{tabular}

\begin{tabular}{lll}
\multicolumn{3}{l}{ Table 2. Biochemical assays } \\
\hline Variable & Result & Reference range \\
\hline Fasting glucose, $\mathrm{mg} / \mathrm{dL}$ & 85.4 & $59-115$ \\
$\mathrm{HbA} 1 \mathrm{C}, \%$ & 4.6 & $4-6.5$ \\
Urea, $\mathrm{mg} / \mathrm{dL}$ & 5 & $7-18$ \\
Sodium, $\mathrm{mmol} / \mathrm{L}$ & 140 & $137-150$ \\
Potassium, $\mathrm{mmol} / \mathrm{L}$ & 3.8 & $3.5-5.3$ \\
Chloride, $\mathrm{mmol} / \mathrm{L}$ & 106 & $96-108$ \\
Bicarbonate, $\mathrm{mmol} / \mathrm{L}$ & 26 & $22-29$ \\
Creatinine, $\mu \mathrm{mol} / \mathrm{L}$ & 40 & $45-84$ \\
Magnesium, $\mathrm{mg} / \mathrm{dL}$ & 2.3 & $1.3-2.1$ \\
Total protein, $\mathrm{g} / \mathrm{dL}$ & 6 & $6-7.8$ \\
Albumin, g/dL & 3.5 & $3.5-5.5$ \\
Stool reducing substance & Absent \\
Stool for glucose & Negative \\
Stool for fat globules & Negative \\
Stool for occult blood & Negative \\
\hline
\end{tabular}

\section{Table 3. Hormonal assays}

\begin{tabular}{lll}
\hline Variable & Result & Reference range \\
\hline Thyroid stimulating hormone, $\mathrm{mIU} / \mathrm{L}$ & 1.08 & $0.27-4.2$ \\
Free thyroxine, $\mathrm{ng} / \mathrm{dL}$ & 1.3 & $0.932-1.71$ \\
Cortisol, $\mu \mathrm{g} / \mathrm{dL}$ & 12.34 & $2.3-11.9$ \\
Parathyroid hormone, $\mathrm{pg} / \mathrm{mL}$ & 248.8 & $15-65$ \\
\hline
\end{tabular}

Table 4. Screening test results for rheumatologic and connective tissue disorders

\begin{tabular}{lll}
\hline Variable & Result & Reference range \\
\hline Rheumatoid factor, IU/mL & 7 & $0-14$ \\
Anti-nuclear antibody & Negative & \\
Anti-extracted nuclear antigen & & \\
profile & & \\
Antibodies to nRNP/Sm & \\
Antibodies to Sm & \\
Antibodies to SS-A & \\
Antibodies to SS-B & \\
Antibodies to Rib.P-Protein & \\
Antibodies to Ro-52 & \\
Antibodies to Scl-70 & \\
Antibodies to Jo-1 & \\
Antibodies to CENP B & \\
Antibodies to dsDNA & \\
Antibodies to nucleosomes & \\
Antibodies to histones &
\end{tabular}

Table 5. Bone profile

\begin{tabular}{lll}
\hline Variable & Result & Reference range \\
\hline Calcium, mmol/L & 2.07 & $2.12-2.52$ \\
Corrected calcium, mmol/L & 2.1 & $2.12-2.52$ \\
Inorganic phosphate, $\mathrm{mmol} / \mathrm{L}$ & 0.6 & $0.78-1.65$ \\
\hline 25-OH vitamin $\mathrm{D}, \mathrm{mmol} / \mathrm{L}$ & 17.6 & $75-100$ \\
\hline Alkaline phosphatase, $\mathrm{IU} / \mathrm{L}$ & 109 & $39-117$ \\
\hline Parathyroid hormone, $\mathrm{pg} / \mathrm{mL}$ & 248.8 & $15-65$ \\
\hline & &
\end{tabular}

Bone profile evaluation showed low inorganic phosphate, normal alkaline phosphatase, increased parathyroid hormone and reduced 25-OH vitamin D level (Table 5).

With symptoms and biochemical findings correlated with osteomalacia, the patient underwent further radiological assessment. Radiographs showed small cortical breaks at the proximal part of the left femur and the right scapula (Figures 1 and 2).

To assess dyspepsia and frequent vomiting, upper GI endoscopy was planned but not done, as the patient did not give consent.

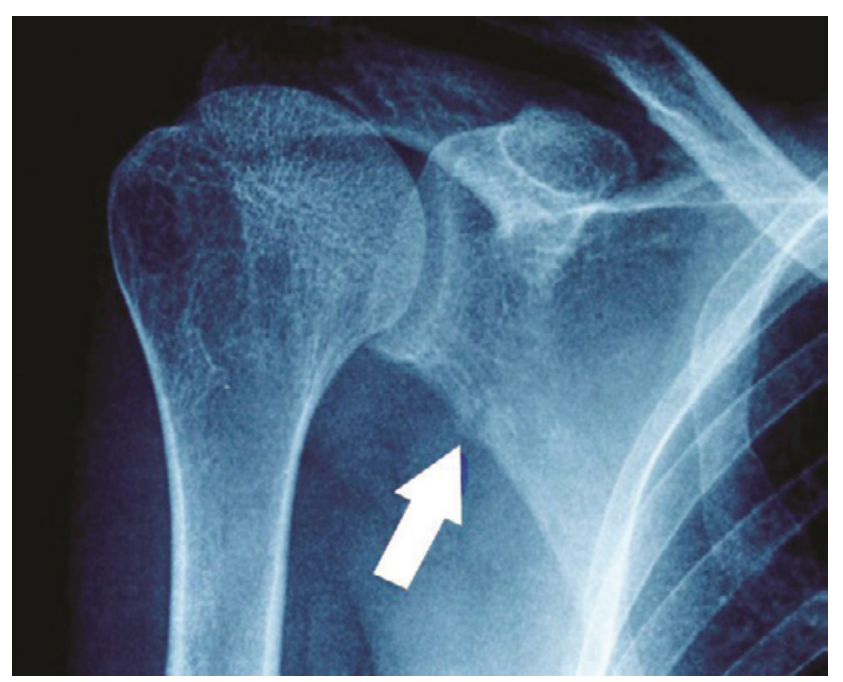

Figure 1. X-ray of the right shoulder showing a Looser zone (pseudofracture) at the outer surface of the scapula.

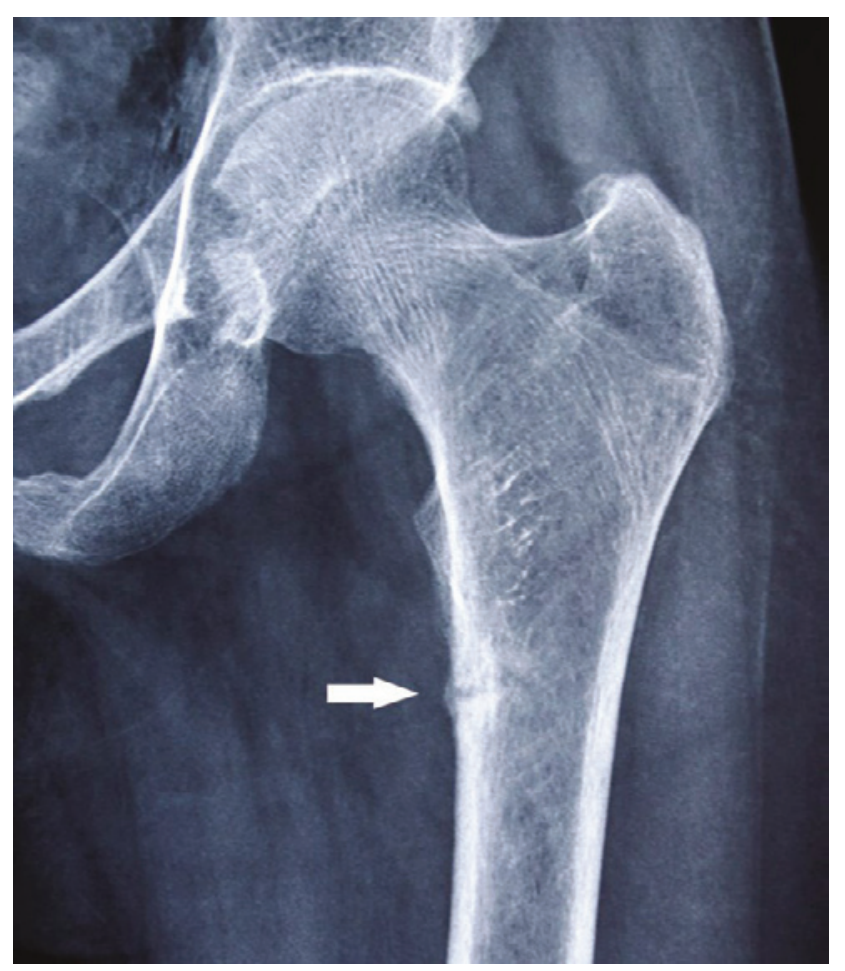

Figure 2. X-ray of the pelvis showing a Looser zone (pseudofracture) at the left femur. 


\section{DISCUSSION}

We evaluated a case of osteomalacia due to vitamin D deficiency as a consequence of previous gastric bypass operation, presenting with long standing, undiagnosed generalized aches and pain. While clinical and radiologic findings (pseudofractures or Looser zones over the periosteal surface of the femur and the outer border of scapula, Figures 1 and 2) favor the diagnosis of osteomalacia, we also encountered some dilemmas in her biochemical findings. Low levels of serum $25-\mathrm{OH}$ vitamin D, calcium and phosphate were accompanied by high parathyroid hormone and upper normal alkaline phosphatase. Although increased serum alkaline phosphatase activity is a typical association of osteomalacia, some may have normal or borderline levels. ${ }^{2}$

A cohort study on 80 Asians and 4 Europeans with osteomalacia revealed that some patients had normal levels of calcium (66\%), phosphate $(81 \%)$ and alkaline phosphatase $(29 \%){ }^{3}$ A study in India also found that serum vitamin D levels may not be correlated with serum alkaline phosphatase levels. ${ }^{4}$ Our case also supported their findings.

Our patient had a significantly elevated PTH, which has been found to be a better determinant of histological osteomalacia than 25-OH vitamin $\mathrm{D}$ in Asian populations. ${ }^{3,5,6}$ Although the definitive diagnosis for osteomalacia is established by bone biopsy with double tetracycline labelling, the history of gastrectomy together with radiologic and biochemical findings are sufficient for the diagnosis in this case. ${ }^{1}$

Osteomalacia is not an uncommon metabolic bone disease in the Southeast Asian region. ${ }^{7}$ It may be found in up to $18 \%$ of patients who underwent gastrectomy for peptic ulcer disease, and $30 \%$ of patients with gastric surgery or bypass for obesity. 2,8 It has been reported that gastric bypass operation predisposes the patients to severe vitamin $\mathrm{D}$ deficiency and osteomalacia in the absence of pharmacologic doses of vitamin D therapy. ${ }^{9}$ The severity depends on the duration and extent of the surgery. Apart from vitamin $\mathrm{D}$, calcium absorption is also impaired due to exclusion of the duodenum. ${ }^{1,8,10}$ The possible mechanism of vitamin D deficiency/osteomalacia is the short duration of interaction of gastric acid and ingested food affecting the activation of pancreatic enzymes. This subsequently leads to impaired absorption of fat, causing deficiency in fatsoluble vitamins A, D, E and K. ${ }^{11}$ Another mechanism is the reduction in gastric volume, causing the patient to consume small quantities and affecting dietary choices. ${ }^{1}$ There is a higher risk of development of metabolic bone disease in those who have undergone Billroth II operation compared to Billroth I, where the duodenum is excluded. ${ }^{1}$ In this case, apart from her previous gastric bypass surgery, the patient also had decreased intake because of her dyspepsia and vomiting. The pigmented skin and reduced sun exposure may also have contributed to osteomalacia.

\section{CONCLUSION AND LEARNING POINTS}

Osteomalacia can present with non-specific aches and pain. It should be highly suspected especially in patients who have undergone gastric bypass operation. The typical findings of both laboratory and radiologic investigations, with the exception of a normal alkaline phosphatase level, were presented in this case report. It is essential to monitor for nutritional deficiencies, especially vitamin $\mathrm{D}$, in these patients.

\section{Ethical Consideration}

Patient consent form has been procured prior to the case report study.

\section{Statement of Authorship}

All authors have given approval to the final version submitted.

\section{Author Disclosure}

All the authors declared no conflicts of interest.

\section{Funding Source}

None.

\section{References}

1. Javorsky BR, Maybee N, Padia SH, Dalkin AC. Vitamin D deficiency in gastrointestinal disease. Pract Gastroenterol. 2006;29:52-72.

2. Weinstein RS. Osteomalacia and rickets. In: Goldman's Cecil Medicine. L Goldman, AI Schafer, eds. $24^{\text {th }}$ ed. Philadelphia: Saunders Elsevier, 2012.

3. Peacey SR. Routine biochemistry in suspected vitamin D deficiency. J R Soc Med. 2004;97(7):322-5.

4. Shaheen S, Noor SS, Barakzai Q. Serum alkaline phosphatase screening for vitamin D deficiency states. J Coll Physicians Surg Pak. 2012;22(7):424-7. http://dx.doi.org/07.2012/JCPSP.424427.

5. Mawer EB, Backhouse J, Hill LF, et al. Vitamin D metabolism and parathyroid function in man. Clin Sci Molec Med. 1975;48(5):349-65. http://dx.doi.org/10.1042/cs0480349.

6. Nisbet JA, Eastwood JB, Colston KW et al. Detection of osteomalacia in British Asians: A comparison of clinical score with biochemical measurements. Clin Sci (Lond). 1990;78(4):383-9.

7. Nimitphong H, Holick MF. Vitamin D status and sun exposure in Southeast Asia. Dermatoendocrinol. 2013;5(1):34-7. http://dx.doi.org/ 10.4161/derm.24054.

8. Bisballe S, Eriksen EF, Melsen F, Mosekilde L, Sorensen OH, Hessov I. Osteopenia and osteomalacia after gastrectomy: Interrelations between biochemical markers of bone remodeling, vitamin D metabolites and bone histomorphometry. Gut. 1991;32(11):1303-7. http://dx.doi.org/10.1136/gut.21.11.1303.

9. Al-Shoha A, Qui S, Palnitkar S, Rao DS. Osteomalacia with bone marrow fibrosis due to severe vitamin D deficiency after a gastrointestinal bypass operation for severe obesity. Endocr Pract. 2009;15(6):528-33. http://dx.doi.org/10.4158/EP09050.ORR.

10. Imawari M, Kozawa K, Akanuma Y, Koizumi S, Itakura H, Kosaka K. Serum 25-hydroxyvitamin D and vitamin D-binding protein levels and mineral metabolism after partial and total gastrectomy. Gastroenterology. 1980;79(2):255-58.

11. Draşovean R. Post-gastrectomy syndromes. Acta Medica Transilvanica 2012;2(2):201-3. 
Authors are required to accomplish, sign and submit scanned copies of the JAFES Author Form consisting of: (1) the Authorship Certification that the manuscript has been read and approved by all authors, and that the requirements for authorship have been met by each author, (2) the Author Declaration that the article represents original material that is not being considered for publication or has not been published or accepted for publication elsewhere, (3) the Statement of Copyright Transfer[accepted manuscripts become the permanent property of the JAFES and are licensed with an Attribution-Share Alike-Non-Commercial Creative Commons License. Articles may be shared and adapted for non-commercial purposes as long as they are properly cited], (4) the Statement of Disclosure that there are no financial or other relationships that might lead to a conflict of interest. For Original Articles involving human participants, authors are required to submit a scanned copy of the Ethics Review Approval of their research. For manuscripts reporting data from studies involving animals, authors are required to submit a scanned copy of the Institutional Animal Care and Use Committee approval. For Case Reports or Series, and Images in Endocrinology, consent forms, are required for the publication of information about patients; otherwise, authors declared that all means have been exhausted for securing such consent. Articles and any other material published in the JAFES represent the work of the author(s) and should not be construed to reflect the opinions of the Editors or the Publisher.

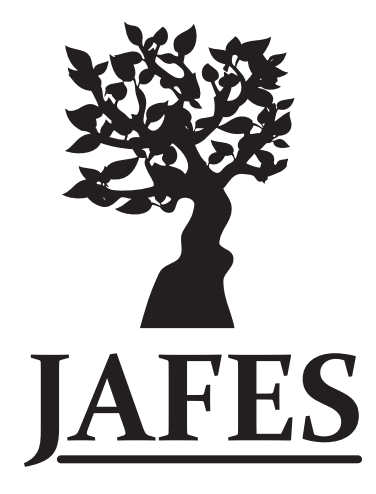

Experience the new JAFES.

Visit us at www.ASEAN-endocrinejournal.org. 